\title{
Olive Mill Wastes: A Source of Bioactive Molecules for Plant Growth and Protection against Pathogens
}

\author{
Fabio Sciubba ${ }^{1,2,+}\left(\mathbb{D}\right.$, Laura Chronopoulou $\left.{ }^{1,+} \mathbb{(}\right)$, Daniele Pizzichini ${ }^{3,+}{ }^{+}$Vincenzo Lionetti ${ }^{4}(\mathbb{D}$, \\ Claudia Fontana ${ }^{5}$, Rita Aromolo ${ }^{5}$, Silvia Socciarelli ${ }^{5}$, Loretta Gambelli ${ }^{6}$, Barbara Bartolacci ${ }^{7}$, \\ Enrico Finotti ${ }^{6}$, Anna Benedetti ${ }^{5}$, Alfredo Miccheli ${ }^{2,8,9}$, , Ulderico Neri ${ }^{5} \oplus$, Cleofe Palocci ${ }^{1,9, *}$ \\ and Daniela Bellincampi ${ }^{4,9, *}$
}

1 Department of Chemistry, Sapienza University of Rome, 00185 Rome, Italy; fabio.sciubba@uniroma1.it (F.S.); laura.chronopoulou@uniroma1.it (L.C.)

2 NMR-Based Metabolomics Laboratory, Sapienza University of Rome, 00185 Rome, Italy; alfredo.miccheli@uniroma1.it

3 Bio-Products-Bio-Processes Laboratory, Division of Biotechnology and Agriculture, Department for Sustainability, ENEA, Casaccia Research Center, 00123 Rome, Italy; daniele.pizzichini@enea.it

4 Department of Biology and Biotechnology Charles Darwin, Sapienza University of Rome, 00185 Rome, Italy; vincenzo.lionetti@uniroma1.it

5 CREA-Council for Agricultural Research and Economics, Research Centre for Agriculture and Environment, 00184 Rome, Italy; claudia.fontana@crea.gov.it (C.F.); rita.aromolo@crea.gov.it (R.A.); silvia.socciarelli@crea.gov.it (S.S.); anna.Benedetti1956@libero.it (A.B.); ulderico.neri@crea.gov.it (U.N.)

6 CREA-Council for Agricultural Research and Economics, Research Centre for Food and Nutrition, 00184 Rome, Italy; loretta.gambelli@crea.gov.it (L.G.); enrico.finotti@crea.gov.it (E.F.)

7 Order of Agronomists and Forestry Doctors, Province of Viterbo, 01100 Viterbo, Italy; studiobartolacci.agr@gmail.com

8 Department of Environmental Biology, Sapienza University of Rome, 00185 Rome, Italy

9 CIABC, Sapienza University of Rome, 00185 Rome, Italy

* Correspondence: cleofe.palocci@uniroma1.it (C.P.); daniela.bellincampi@uniroma1.it (D.B.)

+ Equally contributing authors.

Received: 30 October 2020; Accepted: 4 December 2020; Published: 6 December 2020

Simple Summary: Olive oil is the most common vegetable oil used for human nutrition, and its production represents a major economic sector in Mediterranean countries. The milling industry generates large amounts of liquid and solid residues, whose disposal is complicated and costly due to their polluting properties. However, olive mill waste (OMW) may also be seen as a source of valuable biomolecules including plant nutrients, anthocyanins, flavonoids, polysaccharides, and phenolic compounds. This review describes recent advances and multidisciplinary approaches in the identification and isolation of valuable natural OMW-derived bioactive molecules. Such natural compounds may be potentially used in numerous sustainable applications in agriculture such as fertilizers, biostimulants, and biopesticides in alternative to synthetic substances that have a negative impact on the environment and are harmful to human health.

Abstract: Olive oil production generates high amounts of liquid and solid wastes. For a long time, such complex matrices were considered only as an environmental issue, due to their polluting properties. On the other hand, olive mill wastes (OMWs) exert a positive effect on plant growth when applied to soil due to the high content of organic matter and mineral nutrients. Moreover, OMWs also exhibit antimicrobial activity and protective properties against plant pathogens possibly due to the presence of bioactive molecules including phenols and polysaccharides. This review covers the recent advances made in the identification, isolation, and characterization of OMW-derived bioactive molecules able to influence important plant processes such as plant growth and defend against pathogens. Such studies are relevant from different points of view. First, basic research 
in plant biology may benefit from the isolation and characterization of new biomolecules to be potentially applied in crop growth and protection against diseases. Moreover, the valorization of waste materials is necessary for the development of a circular economy, which is foreseen to drive the future development of a more sustainable agriculture.

Keywords: Olea europaea L.; olive mill wastes; plant growth; plant nutrition; plant protection; phenols; oligosaccharides; bioactive molecules

\section{Introduction}

Olive tree (Olea europaea L.) cultivation for olive oil production is one of the most ancient agricultural practices known by mankind. Olive oil is an important component of the Mediterranean diet known for its high nutritional properties and beneficial health effects. On average, 3 million tons of olive oil are produced around the world every year and 2 million tons of this production takes place in the European Union (EU) representing the first producer, exporter, and consumer of olive oil in the world. The Mediterranean area alone including Spain, Italy, Greece, and Portugal covers around $99 \%$ of the olive oil EU production [1].

Olive oil extraction includes washing of olive fruits, fruit crushing, malaxation to brake off the emulsion and facilitate coalescence, and finally oil separation and extraction.

Olive oil extraction processes have improved over time due to the intensification of oil production and to the modernization of the technology aimed to upgrade the quality of the final product.

The milling industry generates in a short period, usually 4 months (October-January), large amounts of waste (olive mill wastes, OMWs). For instance, an estimated average volume of olive mill wastewater (OMWW) ranging from about 0.3 to $1.2 \mathrm{~m}^{3} /$ tons of processed olives and an average quantity of solid residue ranging from 500 to $735 \mathrm{~kg} /$ tons of processed olives have been reported depending on the adopted extraction systems [2]. OMWs due to their acidity, high levels of biological oxygen demand (BOD) and chemical oxygen demand (COD) are characterized by a high polluting and phytotoxic degree [3]. On the other hand, OMWs are a source of valuable molecules including plant nutrients, anthocyanins, flavonoids, polysaccharides, and several phenolic compounds [4-6] with potential industrial applications as fertilizers, antioxidants, antifungal and antibacterial drugs, cytoprotective agents, gelling and stabilizing agents in food preservation $[4,7]$. Consequently, significant efforts have been devoted to the transition from OMW detoxification to its valorization by optimizing the recovery of high added-value bioactive compounds to be commercially reused.

The increasing consumption of vegetables and the ongoing climate changes, with negative effects on crop production and plant diseases diffusion, requires the large utilization of stimulants, fertilizers, and pesticides to improve plant growth, crop yield, and phytopathogens control [8]. The future challenge for modern agriculture is to operate in a sustainable way reducing the over-application of synthetic fertilizers and pesticides that have a negative impact on the environment and on human health and high persistence in the ecosystems. As an alternative to synthetic chemicals, biostimulants and biopesticides are the best candidates for sustainable integrated crop productivity and pest management $[9,10]$. Bioactive molecules with growth promotion and antimicrobial effects, identified and characterized in OMW by-products, have stimulated many researchers to employ these compounds as biostimulants, biopesticides, and plant protectants for crop improvement. However, more extensive field research is required to evaluate their effects to solve serious plant diseases affecting commercially important crops with a sustainable, large-scale, agro-economical perspective.

This review summarizes recent advances and multidisciplinary approaches in the identification and possible agronomic exploitation of valuable natural OMW-derived bioactive compounds. The acquired knowledge could also lead to the discovery of new plant growth and disease resistance regulators. 


\section{Olive oil Extractive Methods and Olive Mill Wastes}

From the classic traditional discontinuous system, modern mills have moved to the use of continuous cycle extraction processes including two-, three-phase decanter systems [3] and, more recently, multi-phase decanter (MPD) technology in which all the oil extraction steps take place automatically and in succession with higher efficiency and capacity of centrifuge-based extraction [11].

In the three-phase decanter system, warm water up to $50 \mathrm{~L}$ for $100 \mathrm{~kg}$ olive paste is added during malaxation to enhance oil extraction. At the end of the process, a large quantity of OMWWs $\left(0.3-1.2 \mathrm{~m}^{3} /\right.$ tons of processed olives) and dried olive pomace (DOP) (about $580 \mathrm{~kg} /$ tons of processed olives; $55 \%$ moisture) are produced [2].

The two-phase decanter system requires lower water addition, thus smaller amounts of OMWWs (about $0.2-0.3 \mathrm{~m}^{3} /$ tons of processed olives) are generated and a semi-solid waste, defined wet olive pomace (WOP) (about $740 \mathrm{~kg} /$ tons of processed olive; 62\% moisture) is produced [2]. The WOP treatment is difficult due to the high moisture and high concentration in solids, lipids, carbohydrates, and polyphenols [12].

The MPD technology is a modern two-phase system performed without adding water during the process. The introduction of a pulp-kernel separation system produces a dehydrated kernel-enriched fraction and a novel by-product, named Patè olive cake (POC) recovered during and not after the milling process by an exclusively mechanical treatment. POC consists of a wet fraction composed by olive pulp, olive skin, and vegetative water. POC is rich in several bioactive molecules, more concentrated with respect to OP derived from three- or two-phase systems [13-16].

OMWW is an expensive waste to dispose of and a major environmental concern in olive producing countries due to its high pollutant charge. OMWW is a dark-brown liquid ( $\mathrm{pH} 3-6)$, constituted by a stable emulsion of vegetative water, process water, olive oil residues, and fragments of olive pulp. The OMWW composition depends on the extraction system, processed fruits, and processing conditions. OMWW consists of water (83-94\% w/w) and organic compounds (4-18\% w/w) including sugars, polysaccharides, tannins, organic acids, phenolic compounds, and lipids [17]. Its great complexity and variability in chemical composition represents a limit to its direct use as a raw material for industrial purposes.

\section{Active Molecules in OMW and Their Analytical Characterization}

In order to valorize wastes and introduce valuable by-products into the production cycle, it is of paramount importance to define their chemical-physical properties, as well as their chemical composition. For a long time, the most important parameters to define wastes were the chemical-physical ones, such as total solid, volatile solid, fixed solid, oil and grease content, polyphenol content, volatile phenol content, organic nitrogen, COD, and reducing sugar content.

More recently, analytical platforms were employed to better characterize the OMW parameters and a greater emphasis was placed on the evaluation of the antioxidant properties of these matrices $[18,19]$.

The most used methods in order to detect the antioxidant capacity of single or multiple molecules, are oxygen radical absorbance capacity [20], total radical trapping antioxidant parameter [21], Ferric reducing antioxidant power [22], antioxidant reaction with an organic cation radical [23], (diphenyl-1-picrythydrazyl) copper (II) reduction capacity [24], and crocin bleaching assay [25,26].

The natural evolution of such studies is the investigation of the composition of OMW in terms of phenols, polyphenols, and sugars with more powerful techniques such as Fourier Transform IR, Mass Spectroscopy, Nuclear Magnetic Resonance Spectroscopy, or a combination of these $[4,18,27-33]$ (see Table 1).

The content of bioactive molecules in OMW is heavily influenced by agronomic factors, such as pedoclimatic conditions of olive groves, as well as olive variety, harvest period, production year, and extraction process, as well as microbial treatments $[6,34,35]$. This observation implies that the chemical characterization of OMW is a step which must be repeated every time a new batch is to be employed for any kind of application [36]. 
Only recently, POC is being considered for other uses in addition to biofuel production $[15,16]$, and as such a more detailed biochemical analysis is necessary. HPLC chromatography and gas mass spectroscopy could be fast and economical methods to detect phenols [37], while hyphenated platforms such as ultra-performance liquid chromatography coupled with a mass spectrometry detector without pre-treatment of the sample [38] can provide greater selectivity and sensitivity. A summary of the most recent studies concerning the bioactive molecules of OMW is reported in Table 1, and some of the most important molecules and their properties are briefly introduced in the following paragraphs.

Table 1. Recent studies on the characterization of bioactive phenolic compounds in olive mill wastes (OMWs).

\begin{tabular}{|c|c|c|c|c|c|}
\hline Molecule & $\begin{array}{l}\text { Analytical } \\
\text { Platform }\end{array}$ & $\begin{array}{l}\text { Amount in } \\
\text { OMWW (mg/g } \\
\text { Dry Matter) }\end{array}$ & $\begin{array}{c}\text { OMWW } \\
\text { References }\end{array}$ & $\begin{array}{l}\text { Amount in } \\
\text { POC (mg/g } \\
\text { Dry Matter) }\end{array}$ & $\begin{array}{c}\text { POC } \\
\text { References }\end{array}$ \\
\hline \multicolumn{6}{|l|}{ Phenols } \\
\hline Tyrosol & $\begin{array}{l}\text { HPLC, MS, } \\
\text { GC, NMR }\end{array}$ & $1.0-2.8$ & {$[6,32,39-42]$} & $0.4-1$ & [13-16] \\
\hline Hydroxytyrosol & $\begin{array}{l}\text { HPLC, MS, } \\
\text { GC, NMR }\end{array}$ & $0.9-24$ & {$[6,32,39-42]$} & $0.6-2$ & [13-16] \\
\hline Hydroxybenzoic acid & $\begin{array}{l}\text { HPLC, MS, } \\
\text { GC, NMR }\end{array}$ & $2-9$ & {$[6,32,39]$} & l & / \\
\hline Coumaric acid & $\begin{array}{c}\text { HPLC, MS, } \\
\text { GC, NMR }\end{array}$ & $1-2$ & {$[32,39]$} & $0.1-0.6$ & {$[13,16]$} \\
\hline Gallic acid & HPLC, MS & $2-6$ & {$[6,39]$} & / & / \\
\hline Vanillic acid & HPLC, MS & $0.1-0.6$ & {$[6,39]$} & $0.5-0.8$ & [16] \\
\hline Caffeic acid & HPLC, MS & $0.3-1.9$ & {$[6,39]$} & $0.9-5.0$ & [13-15] \\
\hline Hydroxycinnamic acid & HPLC, MS & Detected & [41] & I & 1 \\
\hline \multicolumn{6}{|l|}{ Polyphenols } \\
\hline Quercetin-3-O-glucoside & HPLC, MS & $0.5-2.1$ & {$[39,42]$} & / & / \\
\hline Luteolin-7-O-glucosides & HPLC, MS & $25-55$ & {$[6,40,42]$} & $0.5-1.2$ & {$[13,15]$} \\
\hline \multicolumn{6}{|l|}{ Secoiridoids } \\
\hline Oleuropein & HPLC, MS, GC & 18-92 & {$[6,39-42]$} & $0.1-9.2$ & [14-16] \\
\hline Oleuropein aglycone & HPLC, MS & Detected & [40] & Detected & [14] \\
\hline Ligstroside & HPLC, MS & Detected & [40] & / & 1 \\
\hline Ligstroside aglycone & HPLC, MS & Detected & [40] & / & l \\
\hline Olecantal & HPLC, MS & Detected & {$[40,42]$} & $0.1-0.4$ & [13] \\
\hline
\end{tabular}

\subsection{Phenols and Polyphenols}

Phenolics in plants are mainly synthesized through the phenylpropanoid pathway. Several phenols and polyphenols have been detected in OMWs (e.g., 32.8-103.4 mg/g dry matter in OMWW and $3.0-10.6 \mathrm{mg} / \mathrm{g}$ dry matter in POC, see Table 1), the most important ones being tyrosol, hydroxytyrosol, and their secoiridoid derivatives oleuropein and ligstroside. These compounds play an important role against inflammatory, aging, cancer, bacterial, etc. [43]. From a technological point of view, hydroxytyrosol could be very useful, but its synthesis is very expensive and it is not commercially available in large amounts [44]. For such reasons, the possibility to recover these compounds from natural matrices such as OMW could be an important goal.

\subsection{Secoiridoids}

The most diffused secoiridoids in OMW (e.g., 18-91 mg/g dry matter in OMWW and 0.2-9.6 mg/g dry matter in POC, see Table 1) are derived from elenolic acid, which is often esterified with hydroxytyrosol or tyrosol to form the aglycons of, respectively, oleuropein and ligstroside [29,42,45-47]. Other common derivatives are based on decarboxymethyl dialdehyde elenolic acid (oleacein) instead of elenolic acid. These molecules possess several properties in addition to their antioxidant potential 
with oleuropein, ligstroside, and their aglycons showing a significant antifungal and antimicrobial activity, as well as potential health benefits [48-51].

\subsection{Carbohydrates}

Carbohydrates in OMWs are released following cell wall degradation during the milling process and during the olives ripening process. The knowledge of the composition of the cell wall polysaccharides of the olive fruit and of OMWs is useful to evaluate their potential applications [52]. Green olives, mostly used for oil production, have a cell wall composed of $46 \%$ of pectin polysaccharides (mainly galacturonan and arabinans), 28\% Cellulose, 17\% Glucuronoxylan, 10\% Xyloglucan, 1\% Mannan, and Arabinose-Rich Glycoprotein in traces [53,54]. Differences can be revealed between cultivars and ripening stages. Pectin-related sugars (Galacturonic Acid; GalA, Rhamnose; Rha, and Arabinose; Ara) are abundant in olives early during ripening, whereas hemicellulose monosaccharides (Xylose; Xyl, Mannose; Man, Galactose; Gal, and Glucose; Glc) increase later during maturation [55,56].

Cell wall isolation from OMW typically requires a hot ethanol precipitation followed by an alkali, acid, or solvent treatment. The monosaccharide composition is usually performed by HPAEC-PAD or GS-MS analysis associated with several colorimetric assays [56-58]. Differently from the OP, where insoluble cellulose and hemicelluloses are mainly present, OMWW is enriched in soluble pectins $[58,59]$. Polysaccharides isolated from OMWW are mainly enriched in GalA, followed by Ara, Glc, and Gal [58,60]. Conversely, Nadour et al. found that Glc was the major monosaccharide in the cell wall from OMWW, followed by Rha, Gal, Ara, Man, Xyl, and GalA. GlcA and fucose (Fuc) appear as minor sugars [5]. The differences observed among different studies can be explained by the different extraction or analytical methods used, and/or by different varieties or ripening stages of the olives. Evidence suggests that OMW is a source of partially soluble cellooligo-saccharides (COS), pectooligosaccharides (POS), and xylooligosaccharides (XOS) [61]. These oligomers compose a class of value-added compounds with enormous potential. All these oligosaccharides play a fundamental role as plant growth promoters or as defenders against pathogens [62-65]. Moreover, cell wall-derived products may have different nutritional and physiological benefits [66,67]. Possibly due to a recent interest in these OMW-derived oligosaccharides, a fine characterization of their chemical structure is not yet available in the literature. Such information is essential for designing new paths for the exploitation of OMW and its by-products in agriculture. The presence of glycosylated phenolic acids was also proposed for OMWW [4,5,68].

OMW are also enriched in soluble sugars, including significant amounts of Glc and Man and small quantities of Sucrose and Fructose [69]. Mannose can increase tolerance to salt and osmotic stress as "compatible solute" and can play a role in the responses to pathogen attack, as well as being heavily used in the food industry $[70,71]$. However, caution is required since it can have a negative effect on plant growth and defense when administered to plants in high doses [72]. A polymeric mixture, named polymerin, was also recovered from OMWW. It is composed of polysaccharides $(54.4 \%)$, melanin $(26.1 \%)$, protein $(10.4 \%)$, and minerals $(11.06 \%)$ strongly linked through covalent and hydrogen bonds. Polymerin could be used as a potential amendment, and/or metal biointegrator and as a biofilter for toxic metals [73,74].

\section{Sustainable Processes for the Isolation of Bioactive Molecules from OMWs}

Several extraction methodologies for the recovery of OMW-derived bioactive substances are mostly based on the use of organic solvents. However, there is an increasing need for green and sustainable extraction approaches at low environmental impact. Membrane-based techniques such as microfiltration (MF), ultrafiltration (UF), nanofiltration (NF), and reverse osmosis (RO), constitute one of the most effective approaches to separate, concentrate, and finally recover active compounds [75]. These technologies considered best available techniques (BAT) are characterized by high separation efficiency, easy scale-up, and high productivity. These features make cross-flow processes more performing than conventional separation technologies. The effectiveness of MF as a pre-treatment for 
OMWW clarification was investigated in coupling with the membrane distillation process. The MF permeate was further treated through a membrane distillation stage, in order to obtain both clean water and a fraction containing concentrated phenols and sugars for fertilization purposes [76]. With this strategy, hydroxytyrosol was the main phenolic substance recovered and concentrated to $8.16 \mathrm{~g} / \mathrm{L}$. The UF $50 \mathrm{kDa}$ cut-off was applied to separate the phenolic fraction and to lower the COD content of OMWW [77]. Different operating conditions were evaluated in terms of rejection to: COD, color, total solids, and total phenolic content. The results indicate that the UF in acidic condition is a suitable pre-treatment for OMWW to improve phenolic compounds recovery and environmental impact reduction. Different UF and NF membranes were used to separate from OMWW a pectin and a phenol-enriched fraction. Specific UF membranes (25 and $100 \mathrm{kDa}$ cut-off) were effective to separate pectins from a mixture of cations and phenols. Finally, NF was utilized to separate phenols from cations in the solution [78] making this approach useful to separate different molecules from OMWW. Oligosaccharides fractions $(1-3 \mathrm{kDa}$ ) were separated from WOP treated in a hydrothermal reactor and subjected to further chemical and enzymatical hydrolysis. UF was applied to separate tetra-, tri- and di-galacturonic acids, neutral and acidic xylo-oligosaccharides, and low molecular weight oligosaccharides of xyloglucan [79]. A membrane process based on ceramic UF, polymeric NF, and RO was adopted on water extracts of OP in order to concentrate the target compounds. The UF concentrate contains polyphenols $(550 \mathrm{mg} / \mathrm{L})$ and carbohydrates $(4000 \mathrm{mg} / \mathrm{L})$, in comparison, the NF concentrate shows more polyphenols $(652 \mathrm{mg} / \mathrm{L})$ and less carbohydrates $(3000 \mathrm{mg} / \mathrm{L})$. RO retains the remaining organic fraction returning a clean permeate with a total COD of $284 \mathrm{mg} / \mathrm{L}$ [12].

Photocatalysis has been studied as the OMW pretreatment to be applied before membrane fractionation. In order to achieve economic feasibility of the process, the catalyst must be recovered but immobilized systems cannot be used due to the high opacity of OMWW. Magnetic core titania particles, recoverable by means of a magnetic trap, were developed [80]. Their use permitted efficiently performing the pretreatment process of the wastewater stream, using a suspended photocatalyst photoreactor, and recovering up to $98 \%$ of the catalyst. By adopting photocatalysis as a pretreatment step for membranes, it was possible to increase the process productivity of $19 \%$ on average. COD values below $1.3 \mathrm{~g} / \mathrm{L}$ were measured in the final permeate streams, achieving the quality standards for irrigation.

Supercritical fluid extraction (SFE) is being considered an advantageous eco-sustainable technique for biomass fractionation, starting from solid dehydrated materials [81-83]. Olive leaves have been used as a polyphenols source for SFE. $\mathrm{CO}_{2}$ modified by water was more efficient than that modified by ethanol in extracting oleouropein from olive leaves [84,85]. Water swells the matrix, opening pores, and allowing better access to solutes. Other authors described the use of different waste materials such as pruning biomass, leaves, and exhaust pomace as a source of polyphenols [86]. For all materials, SFE afforded extracts with a higher concentration of total polyphenols and higher antioxidant activity compared to SE. Hydroxytyrosol was the most prominent detected compound. Schievano et al. proposed an integrated biorefinery concept for the management of pomace, using SFE for extracting polyphenols and fatty acids, followed by the thermochemical recovery of energy, biofuels, and materials [87].

\section{Application of OWS and OMW-Derived Bioactive Molecules in Plant Growth and Protection}

\subsection{Effects of $O M W$ as Plant Biostimulants}

The new EU Regulation 2019/1009 [88] defines a plant biostimulant (PB) as: “An EU fertilizing product the function of which is to stimulate plant nutrition processes independently of the product's nutrient content with the sole aim of improving one or more of the following characteristics of the plant or the plant rhizosphere: (i) nutrient use efficiency, (ii) tolerance to abiotic stress, (iii) quality traits, or (iv) availability of confined nutrients in the soil or rhizosphere".

The members of the European Biostimulant Industry Council also proposed general principles and guidelines for trials and assays to be performed to allow PBs to be placed on the EU market [89]. 
In the last 10 years (2011-2020), about 1000 scientific papers were published on PBs and OMWs are recognized as biostimulants, although there is still little specific research on them [90].

Palumbo's research [91] indicates that humic acids extracted from an amendment obtained combining OMWs with a pre-treated organic material derived from solid urban waste can be used as $\mathrm{PB}$ in agriculture, thanks to their positive effects on biomass production, nutrition, and activity of enzymes implied in $\mathrm{N}$ metabolism and glycolysis. Other studies have shown that PB formed as a by-product of the two-stage process of squeezing olive oil can induce an increase in the protein content of maize grains up to $19 \%$ [9]. OMW, at low concentrations, can efficiently trigger positive metabolic and physiological responses in plants [9].

Phenols are important signaling molecules and it has been established that in adequate concentrations they can produce several positive effects in plants, even when they are exogenously applied or present in PB formulations [9,92]. Conversely, at concentrations as high as those normally recorded in OMW, phenols may be responsible for the inhibition of soil microbiome activity and induction of several phytotoxic effects, including reduced seed germination, plant growth impairment, and drops in productivity $[93,94]$.

\subsection{Effects of OMW on Soil Properties and Plant Nutrition}

The effects of land spreading of OMW on soil properties have been investigated and the results show that the effects on soil properties and plant growth are different according to the kind of OMW (liquid or solid, raw or processed). The form and rate in which OMWs are applied to soils play a significant role in determining their effectiveness as organic fertilizers and in soil health [95]. On the other hand, many studies investigated the effects of unprocessed OMWW on soil characteristics, recording negative effects on soil properties [96] and phytotoxic effects in seeds and plants when OMW is used directly as an organic fertilizer [97]. These wastes, due to their acidity, high organic load, high levels of BOD, COD, presence of high and low molecular weight polyphenols, short and long-chain fatty acids, and inorganic substances, can be characterized by a high polluting and phytotoxic degree. The reduction of OMW toxicity has been related to the degradation of phenolic compounds considered as the main responsible for the toxic effects on seed germination, on bacteria and on different species of soil and aquatic invertebrates [98]. Nevertheless, OMWs characteristics make them suitable for use as low-cost soil fertilizers recycling the organic matter and mineral nutrients [99]. Moreover, the clarified OMWW can represent a convenient source of irrigation water in Mediterranean countries suffering from water scarcity [100-105]. To solve the environmental problems linked to OMW disposal costs and allow its application to agricultural soils, several physico-chemical and biotechnological processes have been proposed for the OMW treatment based on evaporation ponds, reverse osmosis, filtration, oxidation, thermal drying, aerobic and anaerobic treatments, composting, phyto-depuration, and phenolic components extraction [106]. The impact on soil properties depends on the techniques used. Treated OMWs have no toxic effects and in general enhance soil fertility and plant growth $[102,107,108]$. However, the technological process application is limited due to the high investment or running cost [109] and the most frequently used ways to dispose of OMW nowadays are the application to agricultural soils of unprocessed OMW or after composting $[33,95,110-113]$ or co-composting [114-116].

From the literature, OMW, solid and liquid, raw or processed forms, may affect soil chemical, physical and biological properties in different ways that, in turn, influence the growth and yield of crops as follows.

- Chemical properties: The physico-chemical characteristics of raw or processed OMW are adequate for an agronomic use as an organic fertilizer such as a slightly acidic $\mathrm{pH}$, a very high content of organic matter, and balanced concentrations of mineral elements [117]. An important advantage of OMW is that it is free of heavy metals and other potential pollutants [118]. Many studies reported the general increase of the organic matter, organic $\mathrm{N}$, macro and micronutrients on the soil, in particular, the available K $[99,109,119,120]$. The long term application of OMW in general 
did not cause significant differences in $\mathrm{pH}, \mathrm{EC}, \mathrm{P}, \mathrm{Na}$. However, $\mathrm{pH}, \mathrm{EC}$, and salinity can increase temporarily in topsoil after spreading high rates (200 $\mathrm{m}^{3} /($ ha*year)) of OMWW [103-105,121-123]. - Physical and hydrological properties: Different results are reported in the function of forms of OMW (solid or liquid), rates of application, and pretreatments.

Land applications of raw or composted PO increase water retention and saturated hydraulic conductivity, reduce bulk density, and enhance the stability of aggregates with improved water availability for the crops. The increase in water holding capacity and wilting point can be attributed to changes in soil structure, which result from increases in soil organic carbon [124-126].

However, the accumulation of salts coming from irrigation with OMWW could lead to the disintegration of the soil structure and therefore the decrease of the hydraulic conductivity and a temporary reduction in the soil infiltration rate. In the topsoil, irrigation with OMWW produced an increase of stability of aggregates, lower bulk density, and relatively higher total porosity, but lower macroporosity [104,127-129].

Further advantages of OMW application is the reduction of erosion, runoff, soil losses [124], and pesticides persistence and mobility, decreasing groundwater risk contamination [130].

- Biological properties: The high polyphenols content of OMW represents the most limiting factor for spreading on soils due to their antimicrobial and phytotoxic effects. Nevertheless, OMW polyphenols are rapidly degraded depending on environmental conditions [100]. In regards to the soil microflora, OMW exercises the following two contrasting actions: It stimulates the development of the microflora by temporarily enriching the soil in carbon and inhibits some microorganisms and phytopathogenic agents due to the presence of antimicrobial substances. Studies report that microbial counts increase with OMW quantities and frequency of spreading $[119,131]$. In particular, aerobic bacteria and fungi increase in proportion with OMW spreading rates. Furthermore, soil respiration [96,99] and soil enzyme activities (dehydrogenase, $\beta$-glucosidase, and urease) seem to be enhanced in OMW-amended soils $[122,123]$.

A study on short and long-term effects of repeated OMWW applications [101] showed a temporary negative effect on microbial biomass carbon but also the ability of soil to restore normal values in the long term. Moreover, on treated soils, despite a reduction of arbuscular mycorrhiza fungal root colonization, an increased presence of arbuscules and vesicles was observed.

- Growth and yield of crops: Almost always positive responses on plant growth and yield performances are reported when treated OMW (by composting or co-composting) are used as a consequence of polyphenols biodegradation. However, fertilizations or irrigations with untreated OMW at high doses can harm seeds germination and have negative effects on plant growth due to the phytotoxic effects of the elevated load of polyphenols and high salinity. Recent articles concerning the effect of OMW on plant growth and yield performances are listed in Table 2.

Table 2. Recent studies on the effects of OMWs on plants growth and yield. * indicates the type of OMW and the plant growth performance

\begin{tabular}{|c|c|c|c|c|c|c|c|c|}
\hline \multirow{3}{*}{$\begin{array}{c}\text { Plant } \\
\text { Organism }\end{array}$} & \multicolumn{4}{|c|}{ OMW } & \multicolumn{2}{|c|}{$\begin{array}{l}\text { Plant Growth } \\
\text { Performance }\end{array}$} & \multirow{3}{*}{ Notes } & \multirow{3}{*}{ References } \\
\hline & \multicolumn{2}{|c|}{ OMWW } & \multicolumn{2}{|c|}{ OP } & \multirow{2}{*}{ Positive } & \multirow{2}{*}{ Negative } & & \\
\hline & Raw & Treated & Raw & Treated & & & & \\
\hline $\begin{array}{l}\text { Italian } \\
\text { ryegrass }\end{array}$ & & * & 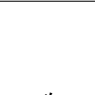 & & * & & $\begin{array}{l}\text { Germination } \\
\text { index }\end{array}$ & [132] \\
\hline $\begin{array}{l}\text { Olive } \\
\text { trees }\end{array}$ & & & $\begin{array}{l}\text { POC } \\
\text { from } \\
\text { MPD }\end{array}$ & $\begin{array}{l}\text { POC } \\
\text { from } \\
\text { MPD }\end{array}$ & * & & $\begin{array}{l}\text { Long-term } \\
\text { field study }\end{array}$ & [110] \\
\hline
\end{tabular}


Table 2. Cont.

\begin{tabular}{|c|c|c|c|c|c|c|c|c|}
\hline \multirow{3}{*}{$\begin{array}{c}\text { Plant } \\
\text { Organism }\end{array}$} & \multicolumn{4}{|c|}{ OMW } & \multicolumn{2}{|c|}{$\begin{array}{l}\text { Plant Growth } \\
\text { Performance }\end{array}$} & \multirow{3}{*}{ Notes } & \multirow{3}{*}{ References } \\
\hline & \multicolumn{2}{|c|}{ OMWW } & \multicolumn{2}{|c|}{ OP } & \multirow{2}{*}{ Positive } & \multirow{2}{*}{ Negative } & & \\
\hline & Raw & Treated & Raw & Treated & & & & \\
\hline Maize & * & & & & * & & $\begin{array}{l}\text { Field trials } \\
\text { calcareous soil }\end{array}$ & [120] \\
\hline $\begin{array}{l}\text { Durum } \\
\text { wheat } \\
\text { Barley }\end{array}$ & * & & & & * & & Field trials & {$[103,105]$} \\
\hline $\begin{array}{l}\text { Olive } \\
\text { trees }\end{array}$ & * & & & & * & & $\begin{array}{l}\text { Long-term } \\
\text { field study }\end{array}$ & [119] \\
\hline $\begin{array}{l}\text { Olive } \\
\text { trees }\end{array}$ & * & & & * & * & & $\begin{array}{l}\text { Long-term } \\
\text { field study }\end{array}$ & [133] \\
\hline $\begin{array}{l}\text { Faba } \\
\text { bean }\end{array}$ & * & & & & $\begin{array}{c}* \\
\text { dose } \\
25 \mathrm{~m}^{3} / \text { ha } \\
*\end{array}$ & & $\begin{array}{l}\text { Pot trials with } \\
\text { different doses }\end{array}$ & [97] \\
\hline $\begin{array}{l}\text { Olive } \\
\text { trees }\end{array}$ & * & & & & $\begin{array}{l}\text { Olive } \\
\text { grove } \\
\text { yield }\end{array}$ & & $\begin{array}{l}\text { Long-term } \\
\text { field study }\end{array}$ & [122] \\
\hline Grapevine & * & & & & * & & $\begin{array}{l}\text { Long-term field } \\
\text { study (11 years) }\end{array}$ & [99] \\
\hline $\begin{array}{l}\text { Olive } \\
\text { plantlets }\end{array}$ & & & * & & & 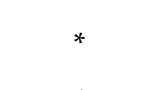 & $\begin{array}{l}\text { pot trials in } \\
\text { greenhouse }\end{array}$ & [134] \\
\hline $\begin{array}{l}\text { Winter } \\
\text { Weath }\end{array}$ & * & * & & & $\begin{array}{c}* \\
\text { (OMWW } \\
\text { treated) }\end{array}$ & $\begin{array}{c}* \\
(\mathrm{OMWW} \\
\text { raw })\end{array}$ & Field trials & [123] \\
\hline
\end{tabular}

\subsection{Effects of $O M W$ as Biopesticides in Plant Protection}

In the agronomic industry, a huge problem is represented by fungal and bacterial pathogens that cause significant crops losses and produce mycotoxins potentially harmful for human health.

Plant diseases are largely addressed using synthetic pesticides that have a negative impact on environment contamination, are harmful to health, and can also generate pest-resistance. Bio-pesticides have been recently described as the best candidates for the control of phytopathogens for a sustainable agriculture.

The application of OMWs by-products in crop protection against pests takes advantage of their antifungal and antimicrobial properties without negative effects on plant growth $[135,136]$.

Several experimental evidences reported the fungicidal activity of OMWW against dangerous phytopathogens.

The inhibitory activity of OMWW on in vitro mycelium growth of Fusarium oxysporum, Pythium spp., Sclerotinia sclerotiorum, Verticillium dahlia, and Botrytis cinerea was reported [137,138]. The strong fungicidal activity of water extracts of WPO, diluted 1:10, was demonstrated against Phytophthora capsica [139]. The filter sterilized OMWW also inhibited the in vitro mycelium growth of B. tulipae, F. oxysporum, Aspergillus niger, and Penicillium spp [140].

Furthermore, the OMWW fruit application strongly reduced $B$. cinerea mold formation in strawberries and red peppers, indicating a possible application of this by-product in fruit protection against post-harvest diseases [138].

The OMW sterilization abolished all these biological effects suggesting that the antifungal and protective effect on fruits and vegetables from post-harvest diseases were possibly due to thermolabile phenolic compounds, although a synergistic effect of phenols with other molecules could not be excluded. 
Increased accumulation of phenolic phytoalexins in plants can promote host defense against pathogens and the activity of phenols in plant defense against phytopathogens have been explored for their application as biopesticides in agriculture [141].

Due to their low solubility in the oil phase, only $2 \%$ of phenols are contained in olive oil. Phenols mainly occur in OP $(\sim 45 \%)$ and in OMWW ( 53\%) [135] by-products making these wastes an important source of these molecules [136].

Caffeic acid, protocatechuic acid, para-coumaric acid, ferulic acid, cinnamic acid, and oleuropein isolated from OP, at a concentration of 1000 ppm, exhibited fungicidal activity against numerous phytopathogens with a higher effect on F. oxysporum and Verticillium sp [142]. A powerful fungicidal effect of phenols extracted from DOP at a concentration of 0.1 and $0.2 \%(w / v)$ was also demonstrated against Alternaria solani, F. culmorum, Phytophthora capsica, and B. cinerea [143].

Evidences indicated that the antifungal effect of OMWW is related to low molecular weight phenols and in particular to hydroxytyrosol (HT) and tyrosol. OMWW and HT-rich extracts inhibited the growth of Pseudomonas syringae pv tomato and Xanthomonas campestris at concentrations of 72 and $40 \mathrm{~g} / \mathrm{L}$, respectively [144]. Interestingly, OMWW at a minimum quantity of $10 \mu \mathrm{L} / \mathrm{mL}$ added to the medium inhibited the in vitro growth of the devastating bacterium Xylella fastidiosa. Moreover, a bacteriostatic effect was exerted by specific mono and polyphenols associated with OWS such as cathecol and methyl cathecol $(1 \mathrm{mM})$, caffeic acid $(1 \mathrm{mM})$, oleuropein $(10 \mathrm{mM})$, and verbascoside $(1 \mathrm{mM})$ [145]. However, the mechanism for X. fastidiosa growth inhibition by phenols is still unknown [146,147].

To understand the molecular basis of HT antifungal activity, different chemically synthetized HT analogues were used against $A$. flavus, A. fumigatus, F. oxysporum, and mycelial growth. HT analogues altered the plasma membrane structure within some minutes after their addition to fungal cultures. The HT analogues effect was associated with the inhibition of transporter mediated xanthine uptake, indicating that the direct effect of HT analogues was the disruption of the fungal plasma membrane integrity and function [148].

The plant cell wall (CW) is a source of bioactive molecules [149]. Cell wall fragments, so called damage-associated molecular patterns (DAMPs), released after enzymatic degradation of CW polysaccharides can improve plant protection, as well as crop yield [150].

OMWW is a good source of polysaccharides. Cellulose, hemicellulose, and pectins are the main carbohydrates identified in olive mill by-products [5]. While insoluble cellulose and hemicelluloses were mainly found in OP, soluble pectic components were observed in OMWW at significant concentrations [58,67,151,152]. Long (polymerization degree DP:10-15) and short pectin fragments (DP:1-8) (oligogalacturonides; OGs) are the best characterized DAMPs and are effective as protectors against phytopathogens [153-155]. These danger signals have been shown to trigger the CW-mediated immunity system leading to the elicitation of defense responses and disease resistance, as well as improve crop yield. Peculiar OGs with prebiotic and antioxidant activity have been fractionated from OMWs $[5,61,156,157]$.

Acidic xylooligosaccharides are antimicrobial active agents [158,159], neutral xyloglucans act as endogenous elicitors [159], and arabinoxylan oligosaccharides can trigger plant immune responses in crops [65]. OGs neutral and acidic xyloglucan oligosaccharides have been detected in olive fruits $[58,151,152]$ and have been isolated and chemically characterized from WOP [79]. Although the role of these olive oligosaccharides in plant defense has not yet been explored, future research could reveal their potential properties as new DAMPs to be used in plant protection.

Recent articles concerning the effect of OMWs and derived bioactive molecules on phytopathogens are listed in Table 3.

It is known that microbial communities have the ability to colonize OMWs and OMW microbiota depends on different physico-chemical conditions of OMWs as well by the cultivation systems, the olive tree cultivar, and olive fruit harvesting practices [160]. The potential biotechnological and industrial applications of indigenous microbiota, isolated from OMWs, in suppressive properties against plant pathogens and OMW bioremediation and valorization are beyond the aims of this review. However, 
it is important to highlight that OWM microbiota could modify the $\mathrm{pH}$ of the olive waste substrates and the composition of bioactive molecules during the OMW conservation period, thus affecting their efficiency as biopesticide in plant protection. Consequently, in the analyses of the biological effects of the OMW-derived bioactive molecules, the effect of a possible microbial colonization, by indigenous microorganisms, needs to be considered and a strict control of the storage and working conditions is highly required, to correctly manage these wastes.

Table 3. Recent studies on the effects of OMWs and derived molecules on microbial phytopathogens.

\begin{tabular}{|c|c|c|c|}
\hline Microbial Organism & Tested Sample & Notes & References \\
\hline $\begin{array}{l}\text { Botrytis tulipae, Fusarium } \\
\text { oxysporum, Aspergillus } \\
\text { niger and Penicillium spp. }\end{array}$ & OMWW & $\begin{array}{l}\text { Reduction of in vitro } \\
\text { mycelium growth } \\
\text { Reduction of Scab-like lesions } \\
\text { B. tulipae on infected tulip bulbs }\end{array}$ & [140] \\
\hline Xylella fastidiosa & $\begin{array}{c}\text { OMWW and } \\
\text { OMWs-derived } \\
\text { MF, UF, and NF fractions }\end{array}$ & $\begin{array}{l}\text { Inhibition of in vitro bacterium } \\
\text { growth at minimum quantity of } \\
\qquad 10 \mu \mathrm{L} / \mathrm{mL}\end{array}$ & [145] \\
\hline $\begin{array}{l}\text { Aspergillus flavus, } \\
\text { Aspergillus. fumigatus, } \\
\text { Fusarium oxysporum }\end{array}$ & Hydroxtyrosol analogues & $\begin{array}{l}\text { Severe inhibition of myceliar growth } \\
\text { at } 100 \mu \mathrm{M}\end{array}$ & [148] \\
\hline Xylella fastidiosa & $\begin{array}{l}\text { Cathecol, Methyl } \\
\text { cathecol, Caffeic acid, } \\
\text { Verbascoside, and } \\
\text { Oleuperin }\end{array}$ & $\begin{array}{l}\text { Inhibition activity due to a } \\
\text { bacteriostatic effect of tested } \\
\text { phenols at } 1 \text { and } 10 \mathrm{mM}\end{array}$ & [145] \\
\hline
\end{tabular}

\section{Conclusions and Future Perspectives}

While OMWs have been for a long time an environmental issue, nowadays they are a source of bioactive molecules to be used in agriculture as natural pesticides, biostimulants, or plant protectants in alternative to harmful agrochemicals. New types of wastes, in particular POC, must be thoroughly studied to identify all potentially useful components, such as oligosaccharides to be employed as plant protectanta, as well as phenols and secoiridoids with potential antimicrobial properties. The definition of molecular mechanisms of action, coupling and complementing the protection activity of phenol and carbohydrate fractions could represent an attractive scientific challenge. In particular, basic research in plant biology may benefit from the isolation and characterization of new biomolecules to be potentially applied in crop growth and protection against diseases.

Researches on OMW as fertilizers have demonstrated two different potential uses: As biostimulants or as soil amendments. The phenolic contents in OMW composition, at adequate concentrations, is able to determine positive metabolic and physiological responses in plants. In addition to phenols, attention should be devoted to olive oligosaccharides for their potential role as elicitors of defense responses. Their characterization and effects as plant elicitors of defense responses have not yet been investigated.

There are few studies aimed to investigate the specific and/or synergistic actions of phenols and oligosaccharides in the complexity of the soil-plant system. Further and more focused researches in these topics are needed as a challenge in the valorization of Olive Mill by-products in formulations complying to the new EU biostimulants regulations and towards a sustainable agriculture.

The OMW effectiveness against phytopathogens has already been investigated and confirmed in many scientific experiences although their recovery with green approaches and their possible use in field applications still need to be further explored. A step in this direction is the ABASA project (Agricultural By-products into valuable Assets for Sustainable Agriculture) recently founded by LazioInnova, Regione Lazio 2017-2020, which has the aim to characterize the phytochemical composition of POC and OMWW fractionated by membrane filtration technologies, as well as to isolate and assess the physiological role of bioactive molecules. 
Author Contributions: Conceptualization, D.B., A.M., D.P., C.P., U.N. and A.B.; writing-original draft preparation, F.S., L.C., V.L., R.A., S.S., C.F., L.G., B.B., E.F., A.B., A.M., U.N., D.P., C.P. and D.B.; writing-review and editing, F.S., L.C., C.P., D.P., A.B., U.N., A.M. and D.B.; supervision, C.P. and D.B. All authors have read and agreed to the published version of the manuscript.

Funding: This research was funded by Lazio Innova-Regione Lazio, "Progetti di gruppi di ricerca-Conoscenza e cooperazione per un nuovo modello di sviluppo" ABASA grant number 85-2017-15080 CUP: B81G18000770002.

Conflicts of Interest: The authors declare no conflict of interest.

\section{References and Note}

1. Olive Oil. Available online: https://ec.europa.eu/info/food-farming-fisheries/plants-and-plant-products/ plant-products/olive-oil_en (accessed on 29 October 2020).

2. Khdair, A.; Abu-Rumman, G. Sustainable Environmental Management and Valorization Options for Olive Mill Byproducts in the Middle East and North Africa (MENA) Region. Processes 2020, 8, 671. [CrossRef]

3. Souilem, S.; El-Abbassi, A.; Kiai, H.; Hafidi, A.; Sayadi, S.; Galanakis, C.M. Olive oil production sector: Environmental effects and sustainability challenges. In Olive Mill Waste; Elsevier: Amsterdam, The Netherlands, 2017; pp. 1-28. ISBN 978-0-12-805314-0.

4. Dermeche, S.; Nadour, M.; Larroche, C.; Moulti-Mati, F.; Michaud, P. Olive mill wastes: Biochemical characterizations and valorization strategies. Process Biochem. 2013, 48, 1532-1552. [CrossRef]

5. Nadour, M.; Laroche, C.; Pierre, G.; Delattre, C.; Moulti-Mati, F.; Michaud, P. Structural Characterization and Biological Activities of Polysaccharides from Olive Mill Wastewater. Appl. Biochem. Biotechnol. 2015, 177, 431-445. [CrossRef] [PubMed]

6. Aggoun, M.; Arhab, R.; Cornu, A.; Portelli, J.; Barkat, M.; Graulet, B. Olive mill wastewater microconstituents composition according to olive variety and extraction process. Food Chem. 2016, 209, 72-80. [CrossRef] [PubMed]

7. Ochando-Pulido, J.M.; Pimentel-Moral, S.; Verardo, V.; Martinez-Ferez, A. A focus on advanced physicochemical processes for olive mill wastewater treatment. Sep. Purif. Technol. 2017, 179, 161-174. [CrossRef]

8. Velásquez, A.C.; Castroverde, C.D.M.; He, S.Y. Plant and pathogen warfare under changing climate conditions. Curr. Biol. 2018, 28, R619-R634. [CrossRef]

9. Drobek, M.; Frac, M.; Cybulska, J. Plant Biostimulants: Importance of the Quality and Yield of Horticultural Crops and the Improvement of Plant Tolerance to Abiotic Stress-A Review. Agronomy 2019, 9, 335. [CrossRef]

10. Ogunnupebi, T.A.; Oluyori, A.P.; Dada, A.O.; Oladeji, O.S.; Inyinbor, A.A.; Egharevba, G.O. Promising Natural Products in Crop Protection and Food Preservation: Basis, Advances, and Future Prospects. Int. J. Agron. 2020, 2020, 1-28. [CrossRef]

11. Coppola, A.; Renzo, G.C.D.; Altieri, G.; D'Antonio, P. Innovative Biosystems Engineering for Sustainable Agriculture, Forestry and Food Production: International Mid-Term Conference 2019 of the Italian Association of Agricultural Engineering (AIIA); Springer Nature: Berlin/Heidelberg, Germany, 2020; ISBN 978-3-030-39299-4.

12. Sygouni, V.; Pantziaros, A.G.; Iakovides, I.C.; Sfetsa, E.; Bogdou, P.I.; Christoforou, E.A.; Paraskeva, C.A. Treatment of Two-Phase Olive Mill Wastewater and Recovery of Phenolic Compounds Using Membrane Technology. Membranes 2019, 9, 27. [CrossRef]

13. Lozano-Sánchez, J.; Bendini, A.; Lecce, G.D.; Valli, E.; Toschi, T.G.; Segura-Carretero, A. Macro and micro functional components of a spreadable olive by-product (pâté) generated by new concept of two-phase decanter. Eur. J. Lipid Sci. Technol. 2017, 119, 1600096. [CrossRef]

14. Antónia Nunes, M.; Costa, A.S.G.; Bessada, S.; Santos, J.; Puga, H.; Alves, R.C.; Freitas, V.; Oliveira, M.B.P.P. Olive pomace as a valuable source of bioactive compounds: A study regarding its lipid- and water-soluble components. Sci. Total Environ. 2018, 644, 229-236. [CrossRef] [PubMed]

15. Cecchi, L.; Bellumori, M.; Cipriani, C.; Mocali, A.; Innocenti, M.; Mulinacci, N.; Giovannelli, L. A two-phase olive mill by-product (pâté) as a convenient source of phenolic compounds: Content, stability, and antiaging properties in cultured human fibroblasts. J. Funct. Foods 2018, 40, 751-759. [CrossRef]

16. Tufariello, M.; Durante, M.; Veneziani, G.; Taticchi, A.; Servili, M.; Bleve, G.; Mita, G. Patè Olive Cake: Possible Exploitation of a By-Product for Food Applications. Front. Nutr. 2019, 6. [CrossRef] [PubMed] 
17. Tundis, R.; Conidi, C.; Loizzo, M.R.; Sicari, V.; Cassano, A. Olive Mill Wastewater Polyphenol-Enriched Fractions by Integrated Membrane Process: A Promising Source of Antioxidant, Hypolipidemic and Hypoglycaemic Compounds. Antioxidants 2020, 9, 602. [CrossRef]

18. Belaid, C.; Khadraoui, M.; Mseddi, S.; Kallel, M.; Elleuch, B.; Fauvarque, J.F. Electrochemical treatment of olive mill wastewater: Treatment extent and effluent phenolic compounds monitoring using some uncommon analytical tools. J. Environ. Sci. 2013, 25, 220-230. [CrossRef]

19. Christoforou, E.; Kylili, A.; Fokaides, P.A. Technical and economical evaluation of olive mills solid waste pellets. Renew. Energy 2016, 96, 33-41. [CrossRef]

20. Moharram, H.; Youssef, M. Methods for Determining the Antioxidant Activity: A Review. Alex. J. Food Sci. Technol. 2014, 11,31-42.

21. Pisoschi, A.M.; Negulescu, G.P. Methods for Total Antioxidant Activity Determination: A Review. Biochem. Anal. Biochem. 2012, 1. [CrossRef]

22. Antolovich, M.; Prenzler, P.D.; Patsalides, E.; McDonald, S.; Robards, K. Methods for testing antioxidant activity. Analyst 2002, 127, 183-198. [CrossRef]

23. Opitz, S.; Smrke, S.; Goodman, B.A.; Yeretzian, C. Methodology for the measurement of antioxidant capacity of coffee: A validated platform composed of three complementary antioxidant assays. Process. Impact Antioxid. Beverage 2014, 253-264. [CrossRef]

24. Pisoschi, A.M.; Cheregi, M.C.; Danet, A.F. Total antioxidant capacity of some commercial fruit juices: Electrochemical and spectrophotometrical approaches. Molecules 2009, 14, 480-493. [CrossRef] [PubMed]

25. Ordoudi, S.A.; Tsimidou, M.Z. Crocin bleaching assay (CBA) in structure-radical scavenging activity studies of selected phenolic compounds. J. Agric. Food Chem. 2006, 54, 9347-9356. [CrossRef] [PubMed]

26. Finotti, E.; Bersani, A.M.; Bersani, E. Total Quality Indexes for Extra-Virgin Olive Oils. J. Food Qual. 2007, 30, 911-931. [CrossRef]

27. Amir, S.; Hafidi, M.; Merlina, G.; Hamdi, H.; Revel, J.-C. Elemental analysis, FTIR and ${ }^{13}$ C-NMR of humic acids from sewage sludge composting. Agronomie 2004, 24, 13-18. [CrossRef]

28. Hafidi, M.; Amir, S.; Revel, J.-C. Structural characterization of olive mill waster-water after aerobic digestion using elemental analysis, FTIR and ${ }^{13}$ C NMR. Process Biochem. 2005, 40, 2615-2622. [CrossRef]

29. Obied, H.K.; Karuso, P.; Prenzler, P.D.; Robards, K. Novel secoiridoids with antioxidant activity from Australian olive mill waste. J. Agric. Food Chem. 2007, 55, 2848-2853. [CrossRef] [PubMed]

30. El Hajjouji, H.; Merlina, G.; Pinelli, E.; Winterton, P.; Revel, J.-C.; Hafidi, M. ${ }^{13}$ C NMR study of the effect of aerobic treatment of olive mill wastewater (OMW) on its lipid-free content. J. Hazard. Mater. 2008, 154, 927-932. [CrossRef]

31. Sannino, F.; De Martino, A.; Capasso, R.; El Hadrami, I. Valorisation of organic matter in olive mill wastewaters: Recovery of highly pure hydroxytyrosol. J. Geochem. Explor. 2013, 129, 34-39. [CrossRef]

32. Zghari, B.; Doumenq, P.; Romane, A.; Boukir, A. GC-MS, FTIR and ${ }^{1} \mathrm{H}^{13} \mathrm{C}$ NMR Structural Analysis and Identification of Phenolic Compounds in Olive Mill Wastewater Extracted from Oued Oussefrou Effluent (Beni Mellal-Morocco). JMES 2017, 8, 4496-4509. [CrossRef]

33. Ait Baddi, G.; Hafidi, M.; Cegarra, J.; Alburquerque, J.A.; Gonzálvez, J.; Gilard, V.; Revel, J.-C. Characterization of fulvic acids by elemental and spectroscopic (FTIR and ${ }^{13} \mathrm{C}-\mathrm{NMR}$ ) analyses during composting of olive mill wastes plus straw. Bioresour. Technol. 2004, 93, 285-290. [CrossRef]

34. Ntougias, S.; Gaitis, F.; Katsaris, P.; Skoulika, S.; Iliopoulos, N.; Zervakis, G.I. The effects of olives harvest period and production year on olive mill wastewater properties-Evaluation of Pleurotus strains as bioindicators of the effluent's toxicity. Chemosphere 2013, 92, 399-405. [CrossRef] [PubMed]

35. Uribe, E.; Pasten, A.; Lemus-Mondaca, R.; Vega-Gálvez, A.; Quispe-Fuentes, I.; Ortiz, J.; Scala, K.D. Comparison of Chemical Composition, Bioactive Compounds and Antioxidant Activity of Three Olive-Waste Cakes. J. Food Biochem. 2015, 39, 189-198. [CrossRef]

36. Gullón, P.; Gullón, B.; Astray, G.; Carpena, M.; Fraga-Corral, M.; Prieto, M.A.; Simal-Gandara, J. Valorization of by-products from olive oil industry and added-value applications for innovative functional foods. Food Res. Int. 2020, 137, 109683. [CrossRef] [PubMed]

37. Mateos, R.; Espartero, J.L.; Trujillo, M.; Ríos, J.J.; León-Camacho, M.; Alcudia, F.; Cert, A. Determination of Phenols, Flavones, and Lignans in Virgin Olive Oils by Solid-Phase Extraction and High-Performance Liquid Chromatography with Diode Array Ultraviolet Detection. J. Agric. Food Chem. 2001, 49, 2185-2192. [CrossRef] 
38. Zafra Gomez, A.; Luzón-Toro, B.; Capel-Cuevas, S.; Morales, J. Stability of Hydroxytyrosol in Aqueous Solutions at Different Concentration, Temperature and with Different Ionic Content: A Study Using UPLC-MS. Food Nutr. Sci. 2011, 2, 1114-1120. [CrossRef]

39. Boutaj, H.; Boutasknit, A.; Anli, M.; Ait Ahmed, M.; El Abbassi, A.; Meddich, A. Insecticidal Effect of Olive Mill Wastewaters on Potosia opaca (Coleoptera: Scarabeidae) Larva. Waste Biomass Valorization 2020, 11, 3397-3405. [CrossRef]

40. Ventura, G.; Calvano, C.D.; Abbattista, R.; Bianco, M.; De Ceglie, C.; Losito, I.; Palmisano, F.; Cataldi, T.R.I. Characterization of bioactive and nutraceutical compounds occurring in olive oil processing wastes. Rapid Commun. Mass Spectrom. 2019, 33, 1670-1681. [CrossRef]

41. Jiménez-Herrera, S.; Ochando-Pulido, J.M.; Martínez-Ferez, A. Comparison between different liquid-liquid and solid phase methods of extraction prior to the identification of the Phenolic fraction present in olive oil washing wastewater from the two-phase olive oil extraction system. Grasas y Aceites 2017, 68. [CrossRef]

42. Silvan, J.M.; Pinto-Bustillos, M.A.; Vásquez-Ponce, P.; Prodanov, M.; Martinez-Rodriguez, A.J. Olive mill wastewater as a potential source of antibacterial and anti-inflammatory compounds against the food-borne pathogen Campylobacter. Innov. Food Sci. Emerg. Technol. 2019, 51, 177-185. [CrossRef]

43. Friedman, M.; Levin, C.E.; Henika, P.R. Addition of phytochemical-rich plant extracts mitigate the antimicrobial activity of essential oil/wine mixtures against Escherichia coli O157:H7 but not against Salmonella enterica. Food Control 2017, 73, 562-565. [CrossRef]

44. De Marco, E.; Savarese, M.; Paduano, A.; Sacchi, R. Characterization and fractionation of phenolic compounds extracted from olive oil mill wastewaters. Food Chem. 2007, 104, 858-867. [CrossRef]

45. Soler-Rivas, C.; Espín, J.C.; Wichers, H.J. Oleuropein and related compounds. J. Sci. Food Agric. 2000, 80, 1013-1023. [CrossRef]

46. Obied, H.K.; Allen, M.S.; Bedgood, D.R.; Prenzler, P.D.; Robards, K.; Stockmann, R. Bioactivity and Analysis of Biophenols Recovered from Olive Mill Waste. J. Agric. Food Chem. 2005, 53, 823-837. [CrossRef] [PubMed]

47. Cardoso, S.M.; Falcão, S.I.; Peres, A.M.; Domingues, M.R.M. Oleuropein/ligstroside isomers and their derivatives in Portuguese olive mill wastewaters. Food Chem. 2011, 129, 291-296. [CrossRef]

48. Ghisalberti, E.L. Biological and pharmacological activity of naturally occurring iridoids and secoiridoids. Phytomedicine 1998, 5, 147-163. [CrossRef]

49. Araújo, M.; Pimentel, F.B.; Alves, R.C.; Oliveira, M.B.P.P. Phenolic compounds from olive mill wastes: Health effects, analytical approach and application as food antioxidants. Trends Food Sci. Technol. 2015, 45, 200-211. [CrossRef]

50. Liu, Y.; McKeever, L.C.; Malik, N.S.A. Assessment of the Antimicrobial Activity of Olive Leaf Extract Against Foodborne Bacterial Pathogens. Front. Microbiol. 2017, 8. [CrossRef]

51. Castro, M.; Japón-Luján, R. State-of-the-art and trends in the analysis of oleuropein and derivatives. TrAC Trends Anal. Chem. 2006, 25, 501-510. [CrossRef]

52. Miranda, I.; Simões, R.; Medeiros, B.; Nampoothiri, K.M.; Sukumaran, R.K.; Rajan, D.; Pereira, H.; Ferreira-Dias, S. Valorization of lignocellulosic residues from the olive oil industry by production of lignin, glucose and functional sugars. Bioresour. Technol. 2019, 292, 121936. [CrossRef]

53. Jiménez, A.; Guillén, R.; Fernández-Bolaños, J.; Heredia, A. Cell Wall Composition of Olives. J. Food Sci. 1994, 59, 1192-1196. [CrossRef]

54. Mafra, I.; Lanza, B.; Reis, A.; Marsilio, V.; Campestre, C.; Angelis, M.D.; Coimbra, M. Effect of ripening on texture, microstructure and cell wall polysaccharide composition of olive fruit (Olea europaea). Physiol. Plant. 2001. [CrossRef] [PubMed]

55. Jiménez, A.; Rodríguez, R.; Fernández-Caro, I.; Guillén, R.; Fernández-Bolaños, J.; Heredia, A. Olive Fruit Cell Wall: Degradation of Pectic Polysaccharides during Ripening. J. Agric. Food Chem. 2001, 49, 409-415. [CrossRef] [PubMed]

56. Huisman, M.M.H.; Schols, H.A.; Voragen, A.G.J. Changes in cell wall polysaccharides from ripening olive fruits. Carbohydr. Polym. 1996, 31, 123-133. [CrossRef]

57. Cardoso, S.M.; Coimbra, M.A.; Lopes da Silva, J.A. Calcium-mediated gelation of an olive pomace pectic extract. Carbohydr. Polym. 2003, 52, 125-133. [CrossRef]

58. Vierhuis, E.; Korver, M.; Schols, H.A.; Voragen, A.G.J. Structural characteristics of pectic polysaccharides from olive fruit (Olea europaea cv moraiolo) in relation to processing for oil extraction. Carbohydr. Polym. 2003, 51, 135-148. [CrossRef] 
59. Galanakis, C.M. Separation of functional macromolecules and micromolecules: From ultrafiltration to the border of nanofiltration. Trends Food Sci. Technol. 2015, 42, 44-63. [CrossRef]

60. Galanakis, C.M.; Tornberg, E.; Gekas, V. A study of the recovery of the dietary fibres from olive mill wastewater and the gelling ability of the soluble fibre fraction. Food Sci. Technol. 2010, 43, 1009-1017. [CrossRef]

61. Cano, M.E.; García-Martin, A.; Comendador Morales, P.; Wojtusik, M.; Santos, V.E.; Kovensky, J.; Ladero, M. Production of Oligosaccharides from Agrofood Wastes. Fermentation 2020, 6, 31. [CrossRef]

62. Suárez, L.; Savatin, D.V.; Salvi, G.; Lorenzo, G.D.; Cervone, F.; Ferrari, S. The non-traditional growth regulator Pectomorf is an elicitor of defense responses and protects Arabodopsis against Botrytis cinerea. J. Plant Pathol. 2013, 95, 177-180. [CrossRef]

63. de Souza, C.A.; Li, S.; Lin, A.Z.; Boutrot, F.; Grossmann, G.; Zipfel, C.; Somerville, S.C. Cellulose-Derived Oligomers Act as Damage-Associated Molecular Patterns and Trigger Defense-Like Responses. Plant Physiol. 2017, 173, 2383-2398. [CrossRef]

64. De Lorenzo, G.; Ferrari, S.; Cervone, F.; Okun, E. Extracellular DAMPs in Plants and Mammals: Immunity, Tissue Damage and Repair. Trends Immunol. 2018, 39, 937-950. [CrossRef] [PubMed]

65. Mélida, H.; Bacete, L.; Ruprecht, C.; Rebaque, D.; del Hierro, I.; Lòpez, G.; Brunner, F.; Pfrengle, F.; Molina, A. Arabinoxylan-Oligosaccharides Act as Damage Associated Molecular Patterns in Plants Regulating Disease Resistance. Available online: https://www.frontiersin.org/articles/10.3389/fpls.2020.01210/full (accessed on 15 October 2020).

66. Roberfroid, M.; Slavin, J. Nondigestible oligosaccharides. Crit. Rev. Food Sci. Nutr. 2000, 40, 461-480. [CrossRef] [PubMed]

67. Galanakis, C.M.; Tornberg, E.; Gekas, V. Dietary fiber suspensions from olive mill wastewater as potential fat replacements in meatballs. LWT Food Sci. Technol. 2010, 43, 1018-1025. [CrossRef]

68. Reem, N.; Pogorelko, G.; Lionetti, V.; Chambers, L.; Held, M.A.; Bellincampi, D.; Zabotina, O.A. Decreased polysaccharide feruloylation compromises plant cell wall integrity and increases susceptibility to necrotrophic fungal pathogens. Front. Plant Sci. 2016, 7, 630. [CrossRef] [PubMed]

69. Guillén, R.; Heredia, A.; Felizón, B.; Jiménez, A.; Montaño, A.; Fernández-Bolaños, J. Fibre fraction carbohydrates in Olea europaea (Gordal and Manzanilla var.). Food Chem. 1992, 44, 173-178. [CrossRef]

70. Alonso, S.; Setser, C. Functional replacements for sugars in foods. Trends Food Sci. Technol. 1994, 5, 139-146. [CrossRef]

71. Stoop, J.; Williamson, J.; Masonpharr, D. Mannitol metabolism in plants: A method for coping with stress. Trends Plant Sci. 1996, 1, 139-144. [CrossRef]

72. Tholakalabavi, A.; Zwiazek, J.J.; Thorpe, T.A. Effect of mannitol and glucose-induced osmotic stress on growth, water relations, and solute composition of cell suspension cultures of poplar (Populus deltoides var.Occidentalis) in relation to anthocyanin accumulation. Vitro Cell. Dev. Biol. Plant 1994, 30, 164-170. [CrossRef]

73. Capasso, R.; de Martino, A.; Arienzo, M. Recovery and Characterization of the Metal Polymeric Organic Fraction (Polymerin) from Olive Oil Mill Wastewaters. J. Agric. Food Chem. 2002, 50, 2846-2855. [CrossRef]

74. Capasso, R.; Pigna, M.; De Martino, A.; Pucci, M.; Sannino, F.; Violante, A. Potential Remediation of Waters Contaminated with $\mathrm{Cr}(\mathrm{III}), \mathrm{Cu}$, and $\mathrm{Zn}$ by Sorption on the Organic Polymeric Fraction of Olive Mill Wastewater (Polymerin) and Its Derivatives. Environ. Sci. Technol. 2004, 38, 5170-5176. [CrossRef]

75. Bazinet, L.; Doyen, A. Antioxidants, mechanisms, and recovery by membrane processes. Crit. Rev. Food Sci. Nutr. 2017, 57, 677-700. [CrossRef] [PubMed]

76. El-Abbassi, A.; Hafidi, A.; Khayet, M.; García-Payo, M.C. Integrated direct contact membrane distillation for olive mill wastewater treatment. Desalination 2013, 323, 31-38. [CrossRef]

77. El-Abbassi, A.; Kiai, H.; Raiti, J.; Hafidi, A. Application of ultrafiltration for olive processing wastewaters treatment. J. Clean. Prod. 2014, 65, 432-438. [CrossRef]

78. Galanakis, C.M.; Tornberg, E.; Gekas, V. Clarification of high-added value products from olive mill wastewater. J. Food Eng. 2010, 99, 190-197. [CrossRef]

79. Lama-Muñoz, A.; Rodríguez-Gutiérrez, G.; Rubio-Senent, F.; Fernández-Bolaños, J. Production, characterization and isolation of neutral and pectic oligosaccharides with low molecular weights from olive by-products thermally treated. Food Hydrocoll. 2012, 28, 92-104. [CrossRef]

80. Stoller, M.; Pulido, J.M.O.; Di Palma, L.; Ferez, A.M. Membrane process enhancement of 2-phase and 3-phase olive mill wastewater treatment plants by photocatalysis with magnetic-core titanium dioxide nanoparticles. J. Ind. Eng. Chem. 2015, 30, 147-152. [CrossRef] 
81. Rizvi, S.S.H. Supercritical Fluid Processing of Food and Biomaterials; Springer: Berlin/Heidelberg, Germany, 1994; ISBN 978-1-4613-5907-4.

82. Baysal, T.; Ersus, S.; Starmans, D.A.J. Supercritical $\mathrm{CO}_{2}$ Extraction of $\beta$-Carotene and Lycopene from Tomato Paste Waste. J. Agric. Food Chem. 2000, 48, 5507-5511. [CrossRef]

83. Díaz-Maroto, M.C.; Pérez-Coello, M.S.; Cabezudo, M.D. Supercritical carbon dioxide extraction of volatiles from spices. Comparison with simultaneous distillation-extraction. J. Chromatogr. A 2002, 947, 23-29. [CrossRef]

84. Şahin, S.; Bilgin, M. Study on Oleuropein Extraction from Olive Tree (Olea europaea) Leaves by Means of SFE: Comparison of Water and Ethanol as CoSolvent. Sep. Sci. Technol. 2012, 47. [CrossRef]

85. Markhali, F.S.; Teixeira, J.A.; Rocha, C.M.R. Olive Tree Leaves-A Source of Valuable Active Compounds. Processes 2020, 8, 1177. [CrossRef]

86. Caballero, A.S.; Romero-García, J.M.; Castro, E.; Cardona, C.A. Supercritical fluid extraction for enhancing polyphenolic compounds production from olive waste extracts. J. Chem. Technol. Biotechnol. 2020, 95, 356-362. [CrossRef]

87. Schievano, A.; Adani, F.; Buessing, L.; Botto, A.; Casoliba, E.N.; Rossoni, M.; Goldfarb, J.L. An integrated biorefinery concept for olive mill waste management: Supercritical $\mathrm{CO}_{2}$ extraction and energy recovery. Green Chem. 2015, 17, 2874-2887. [CrossRef]

88. Regulation (EU) 2019 of the European Parliament and of the Council of 5 June 2019 laying down rules on the making available on the market of EU fertilising products and amending Regulations (EC) No 1069/2009 and (EC) No 1107/2009 and repealing Regulation (EC) No 2003/2003.114.

89. Ricci, M.; Tilbury, L.; Daridon, B.; Sukalac, K. General Principles to Justify Plant Biostimulant Claims. Front. Plant Sci. 2019, 10, 494. [CrossRef] [PubMed]

90. Rouphael, Y.; Colla, G. Editorial: Biostimulants in Agriculture. Front. Plant Sci. 2020, 11, 40. [CrossRef] [PubMed]

91. Palumbo, G.; Schiavon, M.; Nardi, S.; Ertani, A.; Celano, G.; Colombo, C.M. Biostimulant Potential of Humic Acids Extracted From an Amendment Obtained via Combination of Olive Mill Wastewaters (OMW) and a Pre-treated Organic Material Derived From Municipal Solid Waste (MSW). Front. Plant Sci. 2018, 9, 1028. [CrossRef]

92. Ertani, A.; Francioso, O.; Tinti, A.; Schiavon, M.; Pizzeghello, D.; Nardi, S. Evaluation of Seaweed Extracts from Laminaria and Ascophyllum nodosum spp. as Biostimulants in Zea mays L. Using a Combination of Chemical, Biochemical and Morphological Approaches. Front. Plant Sci. 2018, 9. [CrossRef]

93. Leopoldini, M.; Russo, N.; Toscano, M. The molecular basis of working mechanism of natural polyphenolic antioxidants. Food Chem. 2011, 125, 288-306. [CrossRef]

94. García-Sánchez, M.; Garrido, I.; de Casimiro, I.J.; Casero, P.J.; Espinosa, F.; García-Romera, I.; Aranda, E. Defence response of tomato seedlings to oxidative stress induced by phenolic compounds from dry olive mill residue. Chemosphere 2012, 89, 708-716. [CrossRef]

95. Killi, D.; Kavdır, Y. Effects of olive solid waste and olive solid waste compost application on soil properties and growth of Solanum lycopersicum. Int. Biodeterior. Biodegrad. 2013, 82, 157-165. [CrossRef]

96. Mekki, A.; Dhouib, A.; Sayadi, S. Changes in microbial and soil properties following amendment with treated and untreated olive mill wastewater. Microbiol. Res. 2006, 161, 93-101. [CrossRef]

97. Sdiri Ghidaoui, J.; Bargougui, L.; Chaieb, M.; Mekki, A. Study of the phytotoxic potential of olive mill wastewaters on a leguminous plant 'Vicia faba L.'. Water Sci. Technol. 2019, 80, 1295-1303. [CrossRef] [PubMed]

98. Justino, C.I.L.; Pereira, R.; Freitas, A.C.; Rocha-Santos, T.A.P.; Panteleitchouk, T.S.L.; Duarte, A.C. Olive oil mill wastewaters before and after treatment: A critical review from the ecotoxicological point of view. Ecotoxicology 2012, 21, 615-629. [CrossRef] [PubMed]

99. Lanza, B.; Di Serio, M.G.; Di Giovacchino, L. Microbiological and Chemical Modifications of Soil Cultivated with Grapevine Following Agronomic Application of Olive Mill Wastewater. Water Air Soil Pollut. 2020, 231, 86. [CrossRef]

100. Barbera, A.C.; Maucieri, C.; Cavallaro, V.; Ioppolo, A.; Spagna, G. Effects of spreading olive mill wastewater on soil properties and crops, a review. Agric. Water Manag. 2013, 119, 43-53. [CrossRef]

101. Di Bene, C.; Pellegrino, E.; Debolini, M.; Silvestri, N.; Bonari, E. Short- and long-term effects of olive mill wastewater land spreading on soil chemical and biological properties. Soil Biol. Biochem. 2013, 56, 21-30. [CrossRef] 
102. Rusan, M.J.M.; Albalasmeh, A.A.; Zuraiqi, S.; Bashabsheh, M. Evaluation of phytotoxicity effect of olive mill wastewater treated by different technologies on seed germination of barley (Hordeum vulgare L.). Environ. Sci. Pollut. Res. 2015, 22, 9127-9135. [CrossRef]

103. Mohawesh, O.; Al-Hamaiedeh, H.; Albalasmeh, A.; Qaraleh, S.; Haddadin, M. Effect of Olive Mill Wastewater (OMW) Application on Soil Properties and Wheat Growth Performance Under Rain-Fed Conditions. Water Air Soil Pollut. 2019, 230, 160. [CrossRef]

104. Zema, D.A.; Esteban Lucas-Borja, M.; Andiloro, S.; Tamburino, V.; Zimbone, S.M. Short-term effects of olive mill wastewater application on the hydrological and physico-chemical properties of a loamy soil. Agric. Water Manag. 2019, 221, 312-321. [CrossRef]

105. Mohawesh, O.; Albalasmeh, A.; Al-Hamaiedeh, H.; Qaraleh, S.; Maaitah, O.; Bawalize, A.; Almajali, D. Controlled Land Application of Olive Mill Wastewater (OMW): Enhance Soil Indices and Barley Growth Performance in Arid Environments. Water Air Soil Pollut. 2020, 231, 214. [CrossRef]

106. Ahmed, P.M.; Fernández, P.M.; Figueroa, L.I.C.; Pajot, H.F. Exploitation alternatives of olive mill wastewater: Production of value-added compounds useful for industry and agriculture. Biofuel Res. J. 2019, 6, 980-994. [CrossRef]

107. Aquilanti, L.; Taccari, M.; Bruglieri, D.; Osimani, A.; Clementi, F.; Comitini, F.; Ciani, M. Integrated biological approaches for olive mill wastewater treatment and agricultural exploitation. Int. Biodeterior. Biodegrad. 2014, 88, 162-168. [CrossRef]

108. Rusan, M.J.; Albalasmeh, A.A.; Malkawi, H.I. Treated Olive Mill Wastewater Effects on Soil Properties and Plant Growth. Water Air Soil Pollut. 2016, 227, 135. [CrossRef]

109. Chartzoulakis, K.; Psarras, G.; Moutsopoulou, M.; Stefanoudaki, E. Application of olive mill wastewater to a Cretan olive orchard: Effects on soil properties, plant performance and the environment. Agric. Ecosyst. Environ. 2010, 138, 293-298. [CrossRef]

110. Proietti, P.; Federici, E.; Fidati, L.; Scargetta, S.; Massaccesi, L.; Nasini, L.; Regni, L.; Ricci, A.; Cenci, G.; Gigliotti, G. Effects of amendment with oil mill waste and its derived-compost on soil chemical and microbiological characteristics and olive (Olea europaea L.) productivity. Agric. Ecosyst. Environ. 2015, 207, 51-60. [CrossRef]

111. Rajhi, H.; Mnif, I.; Abichou, M.; Rhouma, A. Assessment and valorization of treated and non-treated olive mill wastewater (OMW) in the dry region. Int. J. Recycl. Organ. Waste Agric. 2018, 7, 199-210. [CrossRef]

112. Ameziane, H.; Nounah, A.; Khamar, M.; Zouahri, A. Composting olive pomace: Evolution of organic matter and compost quality. Agron. Res. 2020. [CrossRef]

113. Ait Baddi, G.; Hafidi, M.; Gilard, V.; Revel, J.-C. Characterization of humic acids produced during composting of olive mill wastes: Elemental and spectroscopic analyses (FTIR and $\left.{ }^{13} \mathrm{C}-\mathrm{NMR}\right)$. Agronomie 2003, 23, 661-666. [CrossRef]

114. Aviani, I.; Laor, Y.; Medina, S.; Krassnovsky, A.; Raviv, M. Co-composting of solid and liquid olive mill wastes: Management aspects and the horticultural value of the resulting composts. Bioresour. Technol. 2010, 101, 6699-6706. [CrossRef]

115. Gigliotti, G.; Proietti, P.; Said-Pullicino, D.; Nasini, L.; Pezzolla, D.; Rosati, L.; Porceddu, P.R. Co-composting of olive husks with high moisture contents: Organic matter dynamics and compost quality. Int. Biodeterior. Biodegrad. 2012, 67, 8-14. [CrossRef]

116. Bargougui, L.; Chaieb, M.; Mekki, A. Monitoring Cocomposting of Agro-Wastes from Olive Mill By-Products and Poultry Manures. Environ. Eng. Sci. 2020, 37. [CrossRef]

117. Alburquerque, J. Agrochemical characterisation of "alperujo", a solid by-product of the two-phase centrifugation method for olive oil extraction. Bioresour. Technol. 2004, 91, 195-200. [CrossRef]

118. Fernández-Hernández, A.; Roig, A.; Serramiá, N.; Civantos, C.G.-O.; Sánchez-Monedero, M.A. Application of compost of two-phase olive mill waste on olive grove: Effects on soil, olive fruit and olive oil quality. Waste Manag. 2014, 34, 1139-1147. [CrossRef] [PubMed]

119. Ayoub, S.; Al-Absi, K.; Al-Shdiefat, S.; Al-Majali, D.; Hijazean, D. Effect of olive mill wastewater land-spreading on soil properties, olive tree performance and oil quality. Sci. Hortic. 2014, 175, 160-166. [CrossRef] 
120. Belaqziz, M.; El-Abbassi, A.; Lakhal, E.K.; Agrafioti, E.; Galanakis, C.M. Agronomic application of olive mill wastewater: Effects on maize production and soil properties. J. Environ. Manag. 2016, 171, 158-165. [CrossRef] [PubMed]

121. Chaari, L.; Elloumi, N.; Mseddi, S.; Gargouri, K.; Rouina, B.B.; Mechichi, T.; Kallel, M. Changes in Soil Macronutrients after a Long-Term Application of Olive Mill Wastewater. J. Agric. Chem. Environ. 2015, 4, 1-13. [CrossRef]

122. Magdich, S.; Rouina, B.B.; Ammar, E. Olive Mill Wastewater Agronomic Valorization by its Spreading in Olive Grove. Waste Biomass Valorization 2020, 11, 1359-1372. [CrossRef]

123. Okur, N.; Kayikçioğlu, H.H.; Okur, B.; Yağmur, B.; Sponza Teresa, D.; Kara, R.S. A study of olive mill wastewaters obtained from different treatment processes effects on chemical and microbial properties of a typic xerofluvent soil and wheat yield. Turk. J. Agric. For. 2020, 44, 140-155. [CrossRef]

124. Lozano-García, B.; Parras-Alcántara, L.; del Toro Carrillo de Albornoz, M. Effects of oil mill wastes on surface soil properties, runoff and soil losses in traditional olive groves in southern Spain. CATENA 2011, 85, 187-193. [CrossRef]

125. Nektarios, P.A.; Ntoulas, N.; McElroy, S.; Volterrani, M.; Arbis, G. Effect of Olive Mill Compost on Native Soil Characteristics and Tall Fescue Turfgrass Development. Agron. J. 2011, 103, 1524-1531. [CrossRef]

126. Abu-Rumman, G. Effect of Olive Mill Solid Waste on Soil Physical Properties. Int. J. Soil Sci. 2016, 11, 94-101. [CrossRef]

127. Mahmoud, M.; Janssen, M.; Peth, S.; Horn, R.; Lennartz, B. Long-term impact of irrigation with olive mill wastewater on aggregate properties in the top soil. Soil Tillage Res. 2012, 124, 24-31. [CrossRef]

128. Mohawesh, O.; Mahmoud, M.; Janssen, M.; Lennartz, B. Effect of irrigation with olive mill wastewater on soil hydraulic and solute transport properties. Int. J. Environ. Sci. Technol. 2014, 11, 927-934. [CrossRef]

129. Albalasmeh, A.A.; Alajlouni, M.A.; Ghariabeh, M.A.; Rusan, M.J. Short-Term Effects of Olive Mill Wastewater Land Spreading on Soil Physical and Hydraulic Properties. Water Air Soil Pollut. 2019, 230, 208. [CrossRef]

130. Cabrera, D.; López-Piñeiro, A.; Albarrán, Á.; Peña, D. Direct and residual effects on diuron behaviour and persistence following two-phase olive mill waste addition to soil: Field and laboratory experiments. Geoderma 2010, 157, 133-141. [CrossRef]

131. Magdich, S.; Ben Ahmed, C.; Jarboui, R.; Ben Rouina, B.; Boukhris, M.; Ammar, E. Dose and frequency dependent effects of olive mill wastewater treatment on the chemical and microbial properties of soil. Chemosphere 2013, 93, 1896-1903. [CrossRef]

132. Cavallaro, V.; Maucieri, C.; Barbera, A.C. Lolium multiflorum Lam. cvs germination under simulated olive mill wastewater salinity and pH stress. Ecol. Eng. 2014, 71, 113-117. [CrossRef]

133. Montemurro, F.; Ferri, D.; Fiore, A.; Diacono, M. Suitability of Untreated and Composted Olive Mill By-Products as Amendments in Organic Olive Orchards. Compost Sci. Util. 2014, 22, 216-229. [CrossRef]

134. Endeshaw, S.T.; Lodolini, E.M.; Neri, D. Effects of untreated two-phase olive mill pomace on potted olive plantlets. Ann. Appl. Biol. 2015, 166, 508-519. [CrossRef]

135. El-Abbassi, A.; Saadaoui, N.; Kiai, H.; Raiti, J.; Hafidi, A. Potential applications of olive mill wastewater as biopesticide for crops protection. Sci. Total Environ. 2017, 576, 10-21. [CrossRef]

136. Panzella, L.; Moccia, F.; Nasti, R.; Marzorati, S.; Verotta, L.; Napolitano, A. Bioactive Phenolic Compounds from Agri-Food Wastes: An Update on Green and Sustainable Extraction Methodologies. Front. Nutr. 2020, 7. [CrossRef]

137. Vagelas, I.; Kalorizou, H.; Papachatzis, A.; Botu, M. Bioactivity of Olive Oil Mill Wastewater Against Plant Pathogens and Post-Harvest Diseases. Biotechnol. Biotechnol. Equip. 2009, 23, 1217-1219. [CrossRef]

138. Vagelas, I.; Papachatzis, A.; Kalorizou, H.; Wogiatzi, E. Biological Control of Botrytis Fruit Rot (Gray Mold) on Strawberry and Red Pepper Fruits by Olive Oil Mill Wastewater. Biotechnol. Biotechnol. Equip. 2009, 23, 1489-1491. [CrossRef]

139. Cayuela, M.L.; Millner, P.D.; Meyer, S.L.F.; Roig, A. Potential of olive mill waste and compost as biobased pesticides against weeds, fungi, and nematodes. Sci. Total Environ. 2008, 399, 11-18. [CrossRef] [PubMed] 
140. Lykas, C.; Vagelas, I.; Gougoulias, N. Effect of olive mill wastewater on growth and bulb production of tulip plants infected by bulb diseases. Span. J. Agric. Res. 2014, 12, 233. [CrossRef]

141. Daayf, F.; Hadrami, A.E.; El-Bebany, A.F.; Henriquez, M.A.; Yao, Z.; Derksen, H.; El-Hadrami, I.; Adam, L.R. Phenolic Compounds in Plant Defense and Pathogen Counter-Defense Mechanisms. In Recent Advances in Polyphenol Research; John Wiley \& Sons Ltd.: Hoboken, NJ, USA, 2012; pp. 191-208. ISBN 978-1-118-29975-3.

142. Al-Mughrabi, K.I.; Aburjai, T.A.; Anfoka, G.H.; Shahrour, W. Antifungal activity of olive cake extracts. Phytopathol. Mediterr. 2001, 40, 240-244.

143. Winkelhausen, E.; Pospiech, R.; Laufenberg, G. Antifungal activity of phenolic compounds extracted from dried olive pomace. Bull. Chem. Technol. Maced. 2005, 24, 41-46.

144. Yangui, T.; Sayadi, S.; Dhouib, A. Sensitivity of Pectobacterium carotovorum to hydroxytyrosol-rich extracts and their effect on the development of soft rot in potato tubers during storage. Crop Prot. 2013, 53, 52-57. [CrossRef]

145. Bleve, G.; Gallo, A.; Altomare, C.; Vurro, M.; Maiorano, G.; Cardinali, A.; D’Antuono, I.; Marchi, G.; Mita, G. In vitro activity of antimicrobial compounds against Xylella fastidiosa, the causal agent of the olive quick decline syndrome in Apulia (Italy). FEMS Microbiol. Lett. 2018, 365. [CrossRef]

146. Thielmann, J.; Kohnen, S.; Hauser, C. Antimicrobial activity of Olea europaea Linné extracts and their applicability as natural food preservative agents. Int. J. Food Microbiol. 2017, 251, 48-66. [CrossRef]

147. Robles-Almazan, M.; Pulido-Moran, M.; Moreno-Fernandez, J.; Ramirez-Tortosa, C.; Rodriguez-Garcia, C.; Quiles, J.L.; Ramirez-Tortosa, M. Hydroxytyrosol: Bioavailability, toxicity, and clinical applications. Food Res. Int. 2018, 105, 654-667. [CrossRef]

148. Diallinas, G.; Rafailidou, N.; Kalpaktsi, I.; Komianou, A.C.; Tsouvali, V.; Zantza, I.; Mikros, E.; Skaltsounis, A.L.; Kostakis, I.K. Hydroxytyrosol (HT) Analogs Act as Potent Antifungals by Direct Disruption of the Fungal Cell Membrane. Front. Microbiol. 2018, 9, 2624. [CrossRef] [PubMed]

149. Bellincampi, D.; Cervone, F.; Lionetti, V. Plant cell wall dynamics and wall-related susceptibility in plant-pathogen interactions. Front. Plant Sci. 2014, 5. [CrossRef] [PubMed]

150. Hou, S.; Liu, Z.; Shen, H.; Wu, D. Damage-Associated Molecular Pattern-Triggered Immunity in Plants. Front. Plant Sci. 2019, 10. [CrossRef] [PubMed]

151. Vierhuis, E.; Schols, H.A.; Beldman, G.; Voragen, A.G.J. Structural characterisation of xyloglucan and xylans present in olive fruit (Olea europaea cv koroneiki). Carbohydr. Polym. 2001, 44, 51-62. [CrossRef]

152. Vierhuis, E.; York, W.S.; Kolli, V.S.; Vincken, J.; Schols, H.A.; Van Alebeek, G.W.; Voragen, A.G. Structural analyses of two arabinose containing oligosaccharides derived from olive fruit xyloglucan: XXSG and XLSG. Carbohydr. Res. 2001, 332, 285-297. [CrossRef]

153. Ferrari, S. Oligogalacturonides: Plant damage-associated molecular patterns and regulators of growth and development. Front. Plant Sci. 2013, 4. [CrossRef]

154. Davidsson, P.; Broberg, M.; Kariola, T.; Sipari, N.; Pirhonen, M.; Palva, E.T. Short oligogalacturonides induce pathogen resistance-associated gene expression in Arabidopsis thaliana. BMC Plant Biol. 2017, 17, 19. [CrossRef]

155. Escudero, V.; Jordá, L.; Sopeña-Torres, S.; Mélida, H.; Miedes, E.; Muñoz-Barrios, A.; Swami, S.; Alexander, D.; McKee, L.S.; Sánchez-Vallet, A.; et al. Alteration of cell wall xylan acetylation triggers defense responses that counterbalance the immune deficiencies of plants impaired in the $\beta$-subunit of the heterotrimeric G-protein. Plant J. 2017, 92, 386-399. [CrossRef]

156. Coimbra, M.A.; Cardoso, S.M.; Lopes-da-Silva, J.A. Olive Pomace, a Source for Valuable Arabinan-Rich Pectic Polysaccharides. In Carbohydrates in Sustainable Development I; Rauter, A.P., Vogel, P., Queneau, Y., Eds.; Topics in Current Chemistry; Springer: Berlin/Heidelberg, Germany, 2010; pp. 129-141. ISBN 978-3-642-14837-8.

157. Babbar, N.; Dejonghe, W.; Gatti, M.; Sforza, S.; Elst, K. Pectic oligosaccharides from agricultural by-products: Production, characterization and health benefits. Crit. Rev. Biotechnol. 2015, 1-13. [CrossRef]

158. Christakopoulos, P.; Katapodis, P.; Kalogeris, E.; Kekos, D.; Macris, B.J.; Stamatis, H.; Skaltsa, H. Antimicrobial activity of acidic xylo-oligosaccharides produced by family 10 and 11 endoxylanases. Int. J. Biol. Macromol. 2003, 31, 171-175. [CrossRef] 
159. Claverie, J.; Balacey, S.; Lemaître-Guillier, C.; Brulé, D.; Chiltz, A.; Granet, L.; Noirot, E.; Daire, X.; Darblade, B.; Héloir, M.-C.; et al. The Cell Wall-Derived Xyloglucan Is a New DAMP Triggering Plant Immunity in Vitis vinifera and Arabidopsis thaliana. Front. Plant Sci. 2018, 9. [CrossRef] [PubMed]

160. Ntougias, S.; Bourtzis, K.; Tsiamis, G. The Microbiology of Olive Mill Wastes. BioMed Res. Int. 2013, 2013, 784591. [CrossRef] [PubMed]

Publisher's Note: MDPI stays neutral with regard to jurisdictional claims in published maps and institutional affiliations.

(C) 2020 by the authors. Licensee MDPI, Basel, Switzerland. This article is an open access article distributed under the terms and conditions of the Creative Commons Attribution (CC BY) license (http://creativecommons.org/licenses/by/4.0/). 